\title{
UMA ABORDAGEM DIFERENCIADA DO DIREITO CONTRATUAL NO CURSO TÉCNICO EM ADMINISTRAÇÃO
}

\author{
Keli de Araujo Rocha ${ }^{1}$
}

Favorecer a autonomia do estudante (não mais aluno) é um dos grandes desafios perenes da educação, especialmente, porque traz à tona uma velha discussão sobre o papel do professor no processo de ensino-aprendizagem. Nesse sentido, há inúmeros autores (Michel Foucault, Giles Deleuze, Edgar Morin, Pierre Lévy, Jean Piaget, Gaston Pineau, Paulo Freire, Ivani Fazenda, Hilton Japiassú e tantos outros) que reforçam o protagonismo do estudante como a forma de estabelecer sua responsabilidade perante seu itinerário formativo. Para tanto, o professor não deve assumir simplesmente o papel de mediador do conhecimento, mas dar oportunidade aos estudantes a possibilidade de participar ativamente de seu processo de aprendizagem (CIOLA, 2006), por meio de estratégias que promovam o "aprender a aprender" ou "aprender a conhecer", segundo o Relatório para a UNESCO da Comissão Internacional sobre a Educação para o Século XXI (2010). Esse documento é a maior referência na temática, especialmente porque o Brasil é seu signatário e o incorporou à Lei n. 9.394, de 20 de dezembro de 1996 (Lei de Diretrizes e Bases da Educação) e à legislação inerente.

Essa dificuldade se agrava ainda mais no ensino profissional, que busca apaziguar a dicotomia aparente entre educação e trabalho (SAVIANI, 2007), além dos desafios na formação e preparação dos docentes (BALZAN, 2000; MOROSINI, 2000; PIMENTA; ANASTASIOU, 2002; MASETTO, 2003; CUNHA et al, 2009).

Nesse contexto, a proposta do presente artigo se restringe a relatar uma experiência na condução de atividade avaliativa a partir do conteúdo de direito contratual em sala de aula, desenvolvida com metodologia participativa e que busca estimular a aprendizagem sobre tipos de contrato variados.

Aqui não cabe a pretensão de criar novas metodologias ou sequer comprovar se alguma das já existentes obteria um resultado passível de mensuração, ou ainda, analisar a forma como foi realizado o registro da atividade, mas apenas pretende-se demonstrar que alguns conteúdos permitem uma exploração diferenciada para tornar o conteúdo mais interessante para professores e estudantes.

O processo se inicia no momento em que é trabalhado o conteúdo de direito contratual no Curso Técnico em Administração (assim como na modalidade integrada ao Ensino Médio), quando são apresentados, primeiramente, os marcos conceituais, classificação, formas de pactuação e extinção, além das cláusulas mais comuns. Em seguida, a atividade de pesquisa será iniciada, por meio de um sorteio de tipos de contratos, tanto previstos em lei como os contratos considerados atípicos - que não são regulamentados por lei, porém, são lícitos.

Segundo a proposta da atividade, os estudantes devem pesquisar individualmente um tipo de contrato para apresentação em sala de aula em formato de seminário. As apresentações não têm um tempo determinado: sempre seguem de acordo com o aprofundamento da pesquisa que seu autor tenha lhe dedicado.

Após a explanação da pesquisa realizada pelo estudante, o professor traz suas diversas considerações acerca do contrato apresentado, agregando detalhes de natureza prática e vivencial da elaboração de contratos e da aplicação em cada respectiva área. Ainda é possível aproveitar o espaço para explorar de maneira pormenorizada todos os aspectos daquele assunto

\footnotetext{
${ }^{1}$ Bacharel e Licenciada em Direito, Tecnóloga em Gestão de Turismo, Especialista em Planejamento Educacional e Docência do Ensino Superior; Práticas Gastronômicas e Negócios em Alimentação e Mestre em Educação. Email:keli.rocha2@etec.sp.gov.br.
} 
determinado e fazer comparações entre diferentes tipos de contrato. Em nenhum momento é solicitado ao estudante uma entrega física de documentos ao professor, mas apenas o envio das pesquisas realizadas para o representante de sala, que fica incumbido de compilar todos os materiais enviados em um único documento para consultas futuras pela própria turma.

O registro da atividade acontece por meio de seu planejamento no Plano de Trabalho Docente e respectiva avaliação, segundo os instrumentos proporcionados pelo Centro Estadual de Educação Tecnológica Paula Souza, além da inserção no diário da instituição. Os critérios de avaliação da atividade são apresentados aos alunos antes e após as apresentações: dedicação e envolvimento na atividade de pesquisa, conhecimento sobre o tema pesquisado e comportamento ao longo de todas as apresentações. Como o Centro Paula Souza trabalha seu formato avaliativo como menção e não notas, a mensuração dos resultados é uma atividade rápida que não demanda muito esforço por parte do docente.

Não obstante, é nítido o envolvimento que essa atividade proporciona aos estudantes, os quais trazem uma riqueza de detalhes pesquisados no tocante ao seu tipo de contrato específico. Esse tipo de repertório inclusive já foi utilizado por alguns estudantes para construção de seus próprios contratos em seu ramo de atividade específico.

Por meio dessas pesquisas, torna-se possível abranger assuntos dos mais diversos, como: contrato de viagem (é possível explicar conceitos como overbooking, ponto de equilíbrio e taxa de ocupação que envolvem o setor), todo tipo de contrato ligado a eventos em geral (formatura, casamento, eventos científicos, eventos realizados por alunos, ou aspectos dessa forma de contrato, como locação de espaço, utensílios e demais objetos, som e iluminação, buffet, decoração, segurança, patrocínio, apoio, cheque caução, entre tantos outros subtemas), ou contratos mais específicos para a área de administração (contrato social, prestação de serviços, representação comercial, consignação, franquias, seguro etc.).

Além disso, temas como direitos trabalhistas (contrato de trabalho e de trabalho temporário), tipos de financiamento (contrato de leasing, consórcio, financiamento, entre outros), assim como as garantias (aval, penhor, confissão de dívida, cessão de direitos, entre outras) e até mesmo temas atuais (desenvolvimento de software, assistência médica, propriedade intelectual, entre outros) que, de outra forma, não seriam abordados em sala de aula.

Os tipos de contratos possíveis são infindáveis, o que permite que esse conteúdo seja abordado inclusive por disciplinas correlatas em outros cursos. É muito difícil enumerar a quantidade de temas que são abrangidos nessas aulas; as possibilidades podem ser infinitas. Se a proposta pedagógica é favorecer a autonomia do estudante em se aprofundar na área que melhor lhe aprouver, o objetivo da atividade se justifica.

Certamente, uma atividade nesse formato demanda um conhecimento mais aprofundado por parte do docente acerca do conteúdo ministrado, mediante a exploração dos tipos de contrato abordados. Por essa mesma razão, torna-se possível alegar que o professor precisa de uma vivência profissional na sua área de atuação, o que pode viabilizar uma visualização mais prática da abordagem de tais conteúdos e gerar um interesse maior nos estudantes em elaborar uma boa pesquisa, além de manter um registro completo dos materiais apresentados para possíveis futuras consultas.

Em última instância, o objetivo maior da atividade é desmistificar os conteúdos relacionados à legislação, que costumam ser visualizados de forma estigmatizada, como se não fossem acessíveis a pessoas consideradas leigas. Entretanto, a educação para a autonomia somente pode-se dar com base na cidadania fundamentada no conhecimento e na "consolidação da democracia com justiça social e desenvolvimento fundado em princípios e valores de dignidade humana" (DIAS SOBRINHO, 2009, p. 31). 


\section{Referências}

BALZAN, Newton Cesar. Indissociabilidade de ensino-pesquisa como princípio metodológico. In: VEIGA, Ilma Passos Alencastro; CASTANHO, Maria Eugênia L. M. (Org.). Pedagogia universitária: a aula em foco. Campinas, SP: Papirus, 2000.

CIOLA, Ana Carla Lanzi. Autonomia e Estratégias de Aprendizado. Associação Brasileira de Associações de Professores de Alemão (ABRAPA). São Paulo: ABRAPA, 2006.

CUNHA, Maria Isabel da; SOARES, Sandra Regina; RIBEIRO, Marinalva Lopes (Org.). Docência Universitária: profissionalização e práticas educativas. Feira de Santana, BA: UEFS Editora, 2009.

DIAS SOBRINHO, José. Dilemas da Educação Superior no Mundo Globalizado: sociedade do conhecimento ou economia do conhecimento? São Paulo: Casa do Psicólogo, 2005.

MASETTO, Marcos Tarciso. Aulas vivas. São Paulo: MG Editores Associados, 1992.

MOROSINI, Marília Costa. Docência universitária e os desafios da realidade nacional. In: MORIN, Edgar (Org.). Professor do ensino superior: identidade, docência e formação. Brasília: Plano Editora, 2000. P. 11-20.

ORGANIZAÇÃO DAS NAÇÕES UNIDAS PARA A EDUCAÇÃO, A CIÊNCIA E A CULTURA - UNESCO. Educação: um tesouro a descobrir. Relatório para a UNESCO da Comissão Internacional sobre Educação para o Século XXI. Brasília: UNESCO, 2010.

PIMENTA, Selma Garrido; ANASTASIOU, Léa das Graças Camargos. Docência no ensino superior. São Paulo: Cortez, 2002.

SAVIANI, Demerval. Trabalho e educação: fundamentos ontológicos e históricos. Revista Brasileira de Educação, v. 12, n. 34, jan./abr. 2007. 